\title{
Hydrolysis of Walls and Formation of Sphaeroplasts in Mucor rouxii
}

\author{
By I. F. RAMÍREZ-LEÓN AND J. RUÍZ-HERRERA \\ Departamento de Microbiología, Escuela Nacional de Ciencias Biológicas, \\ Instituto Politécnico Nacional, México I7, D.F., México
}

(Accepted for publication 22 April 1972)

\begin{abstract}
SUMMARY
Walls from Mucor rouxii were partially lysed by an enzymatic complex present in filtrates from cultures of Streptomyces $\mathrm{sp}$. When germinated spores were incubated with the enzymatic complex in a protective medium, osmotically sensitive sphaeroplasts were formed. The enzyme responsible for the degradation of the wall showed optimum activity at $\mathrm{pH} 7.5$ and $32^{\circ} \mathrm{C}$. It was susceptible to the presence of divalent cations. The enzymatic complex released hexosamines (but no $N$-acetyl hexosamines), neutral sugars and uronic acids from purified walls of the fungus. A wall-bound $\alpha$-glucosidase was also rendered soluble by the enzyme. The enzymatic complex hydrolysed chitosan, but not chitin or mucoran, and hydrolysed the walls from only fungi belonging to the Mucorales. It is suggested that the hydrolytic capacity of filtrates from cultures of Streptomyces sp. developed in the presence of walls from $M$. rouxii was due to an enzyme (chitosanase), acting on chitosan but not on chitin.
\end{abstract}

\section{INTRODUCTION}

There is a considerable literature concerning the chemical components of the walls of fungi (for a review see Bartnicki-García, 1968), but little information on how these components are organized in the wall. The use of microbial enzymes which lyse the wall from fungi may be valuable in the study of this problem. In addition, these enzymes could aid the study of problems such as the isolation of cell membranes and mitochondria and the regeneration of walls by protoplasts. Among the micro-organisms which synthesize walllytic enzymes are several species of Bacillus, Pseudomonas, Streptomyces and Micromonospora (Salton, I955; Horikoshi \& Iida, I958; Horikoshi, I959; Furuya \& Ikeda, 1960; Mitchell \& Alexander, I96r, 1963; Ochoa, Garcia Acha, Gason \& Villanueva, 1963; Gascón \& Villanueva, 1964; Tanaka \& Phaff, 1965).

In the present paper the lysis of the wall from Mucor rouxii and the formation of sphaeroplasts from this fungus by the action of an enzymatic complex produced by a strain of Streptomyces sp. is described. The strain of Streptomyces used in this study was reported to hydrolyse walls from Mucor ramannianus by Jones, Bacon, Farmer \& Webley (I968). A preliminary report has appeared elsewhere (Ramírez, Reyes \& Ruíz-Herrera, 1970).

\section{METHODS}

Organisms. Mucor rouxii IM-80 was obtained from S. Bartnicki-García (University of California, Riverside, U.S.A.) and the strain of Streptomyces sp. no. 6 was kindly made available by D. Jones (Macaulay Institute for Soil Research, Aberdeen, Scotland). Other strains were from our culture collection. 
Media. For growth of Mucor rouxii and fungi other than Phytophthora capsici, complex media containing yeast extract, peptone and glucose (YPG) or maltose (YPM) media were used (Bartnicki-García \& Nickerson, I962 a). For growth of $P$. capsici a medium of commercial vegetable juice (Campbell's V-8) diluted $3: \mathrm{Io}$ and neutralized with $0.45 \% \mathrm{CaCO}_{3}$ was used. Streptomyces sp. no. 6 was grown in the following medium (g/l distilled water): $\mathrm{K}_{2} \mathrm{HPO}_{4}, \mathrm{I} \cdot 00 ; \mathrm{MgSO}_{4} \cdot 7 \mathrm{H}_{2} \mathrm{O}, 0.50 ; \mathrm{KCl}, 0.50 ; \mathrm{FeSO}_{4} .7 \mathrm{H}_{2} \mathrm{O}, 0.0 \mathrm{I} ; \mathrm{NH}_{4} \mathrm{NO}_{3}, 5.00$; walls from $M$. rouxii, I·0o. Strains were maintained on slants of the same medium solidified with $2 \%$ agar.

Preparation of walls from fungi. Walls were prepared by the following procedure: Mucor rouxii was grown for $\mathrm{I} 5 \mathrm{~h}$ in New Brunswick fermenters containing 301 of YPG or YPM medium. The mycelium was recovered by filtration, thoroughly washed with water and freeze-dried with a Usifroid lyophilizer. Samples of the dried mycelium were ground with a Wiley cutting mill and homogenized with a Mixolabo (Jouan) homogenizer, each for $20 \mathrm{~min}$. The temperature was kept below $5{ }^{\circ} \mathrm{C}$ by immersing the cup in an ice-salt bath. Walls were centrifuged at $5000 \mathrm{rev} . / \mathrm{min}$ for $10 \mathrm{~min}$, recovered and homogenized again. This procedure was repeated 2 times. Finally, when walls appeared free from cytoplasmic material as judged by microscopical observation of preparations stained with cotton blue they were freeze-dried and kept at $-20{ }^{\circ} \mathrm{C}$ over silica gel. Walls from other fungi were prepared by a similar method, except that growth was obtained in Erlenmeyer flasks. A crude preparation of walls from Phytophthora capsici was obtained by grinding mycelia with a Potter-Elvehjem tissue homogenizer. The preparation was thoroughly washed by centrifugation.

Preparation of the enzymatic complex from Streptomyces sp. no. 6. The actinomycete was grown in shaken Erlenmeyer flasks containing the liquid medium described above for 8 to Io days at $28^{\circ} \mathrm{C}$. The mycelium was eliminated by filtration. The medium was concentrated to $\mathrm{I} / 40$ of its original volume by ultra-filtration, and it was dialysed at $4{ }^{\circ} \mathrm{C}$ for $20 \mathrm{~h}$ against 80 vol of $7 \mathrm{~mm}$-tris- $\mathrm{HCl}$ buffer, $\mathrm{pH} 7 \cdot 5$. The crude enzymatic material was kept at $-20^{\circ} \mathrm{C}$.

Preparation of germinated fungal spores. Erlenmeyer flasks containing YPG medium were inoculated with spore suspensions of the selected fungi and shaken at $28{ }^{\circ} \mathrm{C}$ until almost all spores had germinated ( 6 to $8 \mathrm{~h}$ ). The contents were centrifuged or filtered through sintered glass filters, washed with $50 \mathrm{~mm}$-tris- $\mathrm{HCl}$ buffer, $\mathrm{pH} 8 \cdot 0$, and resuspended in buffer. The suspensions were adjusted to an absorbance of 0.250 to 0.300 at $520 \mathrm{~nm}$ with a Maroc V (Jobin et Ivon) spectrophotometer.

Measurement of activity of the lytic complex from Streptomyces sp. no. 6. Activity was tested on suspensions of spores, walls, chitin and chitosan. It was monitored by the decrease in absorbance of the suspensions measured at $520 \mathrm{~nm}$ with a Maroc V spectrophotometer. Activity was also measured by release of $\mathrm{N}$-acetyl hexosamines, hexosamines, total sugars, reducing material and uronic acids from one or several of the above mentioned substrates. Further details are given in the corresponding experiments.

Preparation of sphaeroplasts from Mucor rouxii. Germinated spores (Io $\mathrm{mg}$ ) were resuspended in $50 \mathrm{~mm}$-tris- $\mathrm{HCl}, \mathrm{pH} 8 \cdot 0$, containing $25 \%$ sucrose and incubated at $32{ }^{\circ} \mathrm{C}$ for 75 min with the enzymatic complex from Streptomyces sp. (60 to I50 $\mu \mathrm{g}$ of protein). Sphaeroplasts appeared after $15 \mathrm{~min}$. Photographs of sphaeroplasts were taken with a Nachet microscope using interference phase-contrast technique.

Chemical methods. Total sugars were measured with the anthrone reagent (Dimler, Schaefer, Wise \& Rist, I952); reducing sugars by the method of Park \& Johnson (I949); acetyl hexosamines as described by Reissig, Strominger \& Leloir (1955); hexosamines by the modified method of Elson \& Morgan (Ashwell, 1957); uronic acids with carbazole 


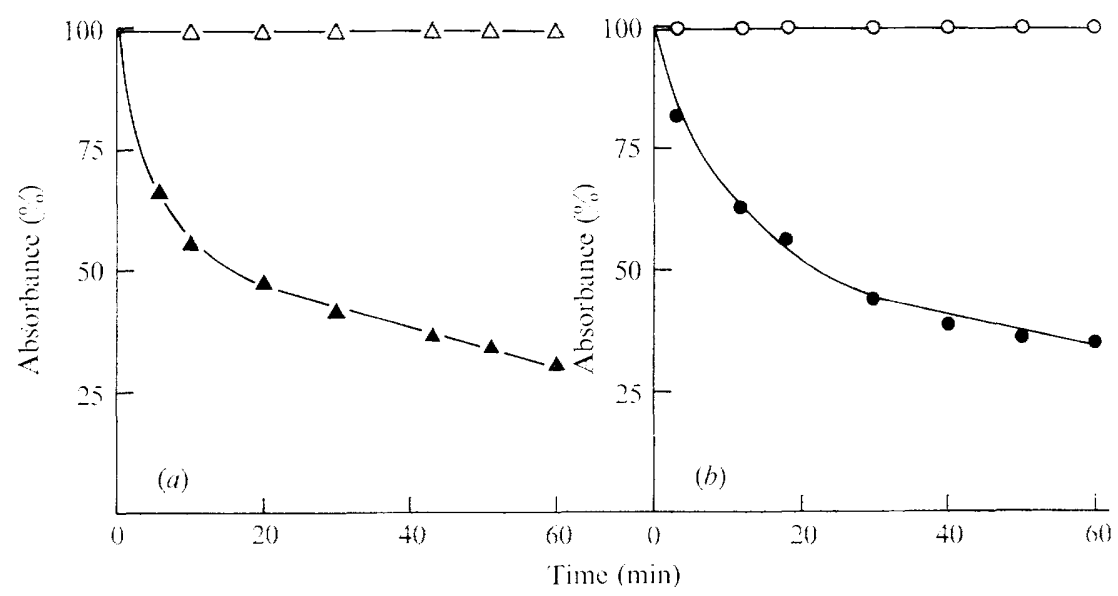

Fig. I. Effect of crude enzyme complex from Streptomyces sp. on germinated spores and walls from Mucor rouxii. Spore suspension $(1 \cdot 2 \mathrm{mg} / \mathrm{ml})(a)$ or wall suspension $(0 \cdot 28 \mathrm{mg} / \mathrm{ml})(b)$ were incubated at $32{ }^{\circ} \mathrm{C}$ in spectrophotometer cuvettes. The final volume was $3.0 \mathrm{ml}$ in $7 \mathrm{mM}$-tris buffer at $\mathrm{pH} 7.5$. Absorbance at $520 \mathrm{~nm}$ was measured at intervals. Open symbols: no enzyme added. Closed symbols: incubated with crude enzyme (60 $\mu \mathrm{g}$ of protein).

(Bitter \& Ewins, I96I); proteins by the method of Lowry, Rosebrough, Farr \& Randall (195I); and phosphate as described by Taussky \& Shorr (1953).

Chemicals. Chitin was purified from commercial crustacean chitin as described by RuízHerrera (1967). Chitosan and mucoran were a gift from S. Bartnicki-García. All other chemicals were of the highest quality available.

\section{RESULTS}

Initially several media were tested to assess the best for growth of the actinomycete. They included the base medium from Skujins, Potgieter \& Alexander (1965) as modified by Jones et al. (I968), and several modifications of Czapek's mineral medium containing walls as the carbon source. $\mathrm{CO}_{2}$ evolution was used as an index of growth. $\mathrm{CO}_{2}$ evolved was drawn in a stream of air into $0.0 \mathrm{I} \mathrm{N}-\mathrm{Ba}(\mathrm{OH})_{2}$ and determined by titration of residual base with $0.0 \mathrm{I} \mathrm{N}-\mathrm{HCl}$. The medium described above gave the highest $\mathrm{CO}_{2}$ values and was used in all further studies.

Accumulation of the lytic complex in the medium increased until the 8 th or 9 th day, and remained constant for about 3 days. Extracellular protein also accumulated in the medium and reached its maximal value $(60 \mu \mathrm{g} / \mathrm{ml})$ at the end of the 6th or 8th day of incubation. For these reasons, an incubation period of 8 days was chosen for further experiments.

Kinetics of wall lysis. When germinated spores or isolated walls from Mucor rouxii were incubated with the enzymatic complex from Streptomyces, turbidity of the suspensions decreased rapidly following characteristic kinetics. The rate of lysis decreased with time and became almost asymptotic (Fig. I). The reduction in rate was not due to enzymatic inactivation, but to the existence of a resistant residue in the walls, since the residue obtained after a first enzymatic attack was not further hydrolysed when incubated with fresh enzymatic complex. Further, the lytic enzyme recovered after hydrolysing a sample of walls was still active and hydrolysed a fresh sample of walls added afterwards (Fig. 2). However chemical analysis showed that the solubilized and resistant fractions were similar in composition. This aspect will be further explained below. 


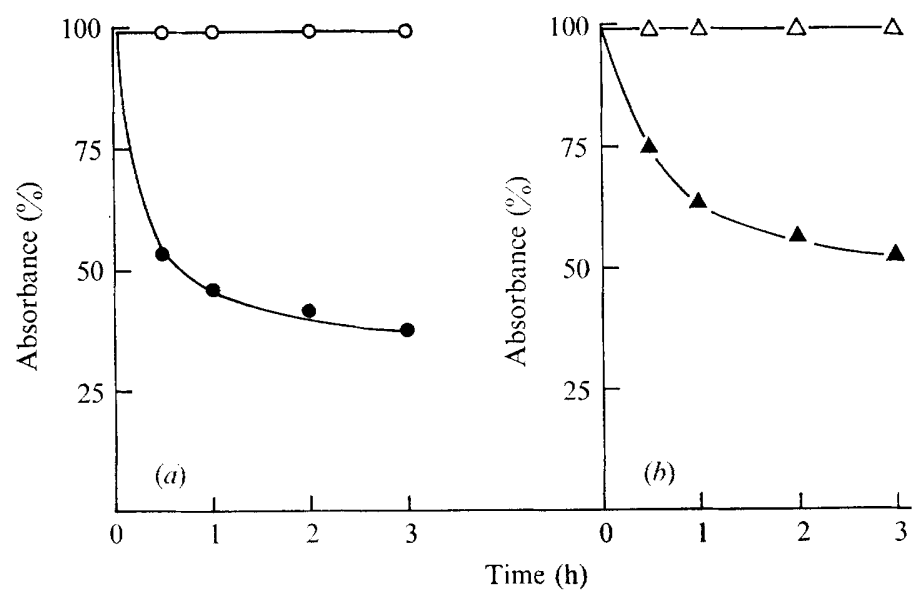

Fig. 2. Effect of crude enzyme complex from Streptomyces sp. on walls from Mucor rouxii. (a) Walls $(2.5 \mathrm{mg})$ were incubated in the conditions specified for Fig. I. Absorbance was measured at $520 \mathrm{~nm}$. Open symbols: no enzyme added. Closed symbols: $300 \mu \mathrm{g}$ of protein of lytic enzyme added. (b) After $24 \mathrm{~h}$ of incubation, material from $(a)$ was centrifuged. Lytic enzyme (300 $\mu \mathrm{g}$ of protein) was added to the residue; $2.5 \mathrm{mg}$ of walls were resuspended in the supernatant. Both samples were again incubated and absorbance measured at intervals. $\triangle$, Residue from $(a)$ with fresh enzyme: $\boldsymbol{\Delta}$, supernatant from $(a)$ with fresh walls.

Characteristics of the enzymatic complex from Streptomyces sp. no. 6 . The effect of $\mathrm{pH}$, temperature and divalent cations on lytic activity was tested. Activity of the enzyme depended on the $\mathrm{pH}$ and also on the composition of the buffer used. In the presence of cationic buffers, activity increased with $\mathrm{pH}$, whereas with anionic buffers, activity decreased with $\mathrm{pH}$. Results obtained with tris buffer (Fig. 3) show optimum activity at $\mathrm{pH} 7 \cdot 6$. The optimum temperature was $32{ }^{\circ} \mathrm{C}$ and activity decreased sharply at other temperatures (Fig. 4). All divalent cations tested were inhibitory. Complete inhibition was obtained when either $\mathrm{Zn}^{2+}$, $\mathrm{Co}^{2+}$ or $\mathrm{Hg}^{2+}\left(\mathrm{I} \times \mathrm{IO}^{-3} \mathrm{M}\right)$ were added to incubation mixtures, but $\mathrm{Mn}^{2+}, \mathrm{Ca}^{2+}$ or $\mathrm{Mg}^{2+}$ added separately were less inhibitory (Fig. 5).

Chemical composition of material released from walls by the lytic complex. When walls from Mucor rouxii were incubated with the lytic complex from Streptomyces sp. no. 6, neutral sugars, hexosamines (but no $\mathrm{N}$-acetyl hexosamines) and uronic acids were released to the supernatant. Release of all the components, and decrease in turbidity followed similar kinetics (Fig. 6). When the solubilized material was hydrolysed with $6 \mathrm{~N}-\mathrm{HCl}$, the amount of glucosamine increased about threefold, suggesting that, on average, the hexosaminecontaining molecules had three residues of amino sugars.

In a further experiment, a sample of $30 \mathrm{mg}$ of walls from Mucor rouxii was incubated at $32{ }^{\circ} \mathrm{C}$ for $24 \mathrm{~h}$ with $3 \mathrm{ml}$ of enzymatic complex from Streptomyces. The final volume was adjusted to $15 \mathrm{ml}$, with $50 \mathrm{mM}$-tris at $\mathrm{pH}$ 8. The mixture was filtered and the insoluble residue was washed and freeze-dried. It appeared as a fluffy whitish material which weighed $6 \mathrm{mg}$. The chemical composition of the solubilized material and residue appears in Table I. The gross chemical composition of both fractions was very similar. However the supernatant contained slightly higher values of phosphate, total sugars and hexosamine, whereas the amounts of uronic acids and proteins were slightly higher in the insoluble residues. Recovery was 93 to $99 \%$. The amount of phosphorus in the walls was much lower than the value reported for hyphal or yeast walls obtained from Mucor rouxii by Bartnicki-García \& Nickerson $(1962 b)$. When walls obtained from mycelium grown in YPM medium were 


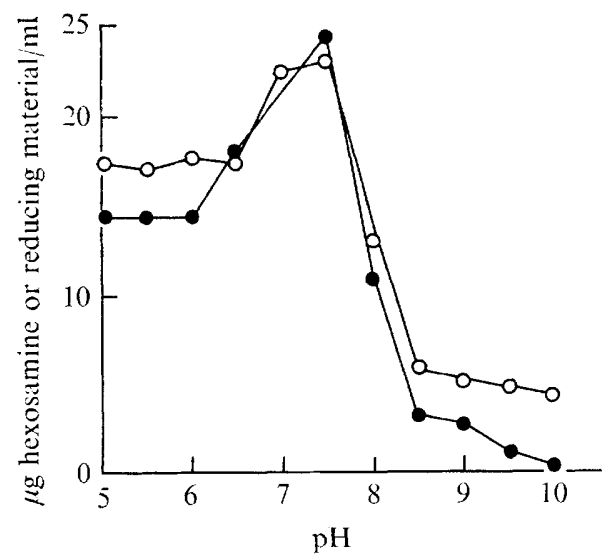

Fig. 3

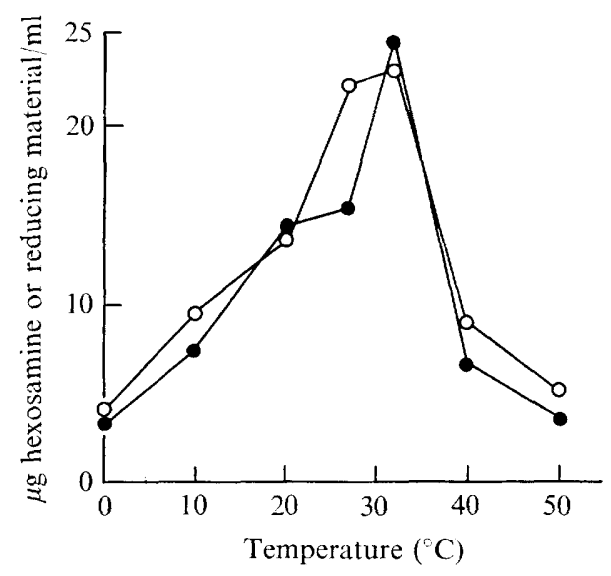

Fig. 4

Fig. 3. Effect of $\mathrm{pH}$ on the activity of lytic enzyme. Samples containing $\mathrm{I} \cdot \mathrm{O} \mathrm{mg}$ of walls were incubated at $32{ }^{\circ} \mathrm{C}$ with crude enzyme ( $60 \mu \mathrm{g}$ of protein) in $50 \mathrm{mM}$-tris at the indicated values of $\mathrm{pH}$. The final volume was $2.0 \mathrm{ml}$. After $3 \mathrm{~h}$, the sample was centrifuged and hexosamines and reducing material in the supernatant were measured. Closed circles: hexosamines in incubation medium $(\mu \mathrm{g} / \mathrm{ml})$; open circles: reducing material expressed as glucose $(\mu \mathrm{g} / \mathrm{ml})$.

Fig. 4. Effect of temperature on activity of lytic enzyme. Samples containing $\mathrm{I} \cdot \mathrm{O} \mathrm{mg}$ of walls were incubated in $50 \mathrm{~mm}$-tris- $\mathrm{HCl}$ buffer, $\mathrm{pH} 7 \cdot 5$. The final volume was $2.0 \mathrm{ml}$. After $3 \mathrm{~h}$ the sample was centrifuged and hexosamines and reducing material in the supernatant were measured. Closed circles: hexosamines $(\mu \mathrm{g} / \mathrm{ml})$; open circles: reducing material expressed as glucose $(\mu \mathrm{g} / \mathrm{ml})$.

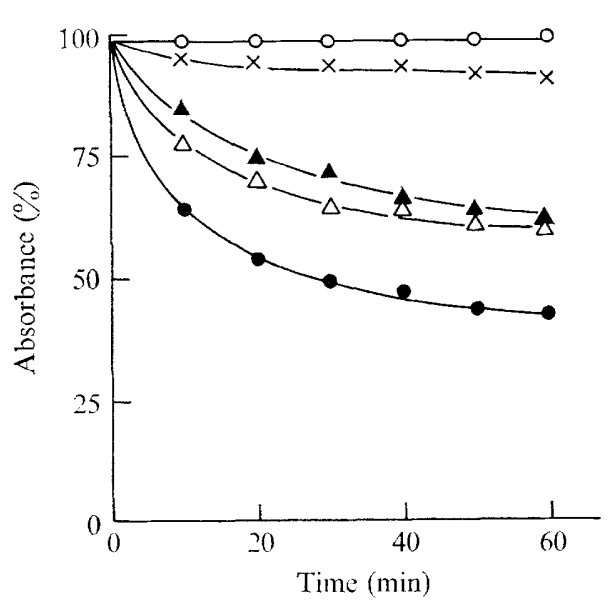

Fig. 5

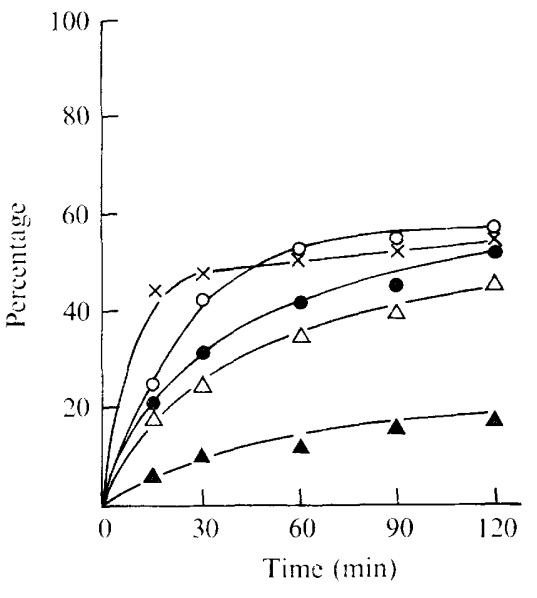

Fig. 6

Fig. 5. Effect of divalent cations on lysis of walls of Mucor rouxii by Streptomyces enzyme complex. Samples containing $1.5 \mathrm{mg}$ of walls were incubated in spectrophotometer cuvettes with $60 \mu \mathrm{g}$ of protein of crude enzyme in the presence of metallic chlorides ( $\mathrm{I} \mathrm{mm}$ ). The final volume was $3.0 \mathrm{ml}$ in $50 \mathrm{~mm}$-tris- $\mathrm{HCl}$ buffer, $\mathrm{pH} 8.0$ and temperature $32^{\circ} \mathrm{C}$. Absorbance was measured at $520 \mathrm{~nm}$. $O$, With either I mM- $\mathrm{Zn}^{2+}$, I mM- $\mathrm{Co}^{2+}$ or I $\mathrm{mM}^{-\mathrm{Hg}^{2+}} ; \times$, with $\mathrm{Mn}^{2+}$; $\boldsymbol{\Delta}$, with $\mathrm{Mg}^{2+} ; \triangle$, with $\mathrm{Ca}^{2+}$; , control, no divalent cation added.

Fig. 6. Release of components from walls of Mucor rouxii by Streptomyces enzyme complex. Walls ( $124 \mathrm{mg}$ ) were resuspended in $54 \mathrm{ml} 7 \mathrm{~mm}$-tris- $\mathrm{HCl}$ buffer, $\mathrm{pH} 7.5$, and $8 \mathrm{ml}$ of enzyme $(4.8 \mathrm{mg}$ of protein) was added. Starting at time of enzyme addition, $10 \mathrm{ml}$ samples were taken and change of absorbance $(\%)$ was recorded $(\triangle)$ and the material was centrifuged and analysed; uronic acids $(x)$, total sugars $(\mathbf{O})$ and hexosamines $(\mathbf{\Delta})$. A sample of each supernatant was hydrolysed with acid and hexosamines were measured $(\mathrm{O})$. Data are expressed as percentage of each component released, taking as $100 \%$ the amount of component present in an acid-hydrolysate obtained from $124 \mathrm{mg}$ of $M$. rouxii walls. 


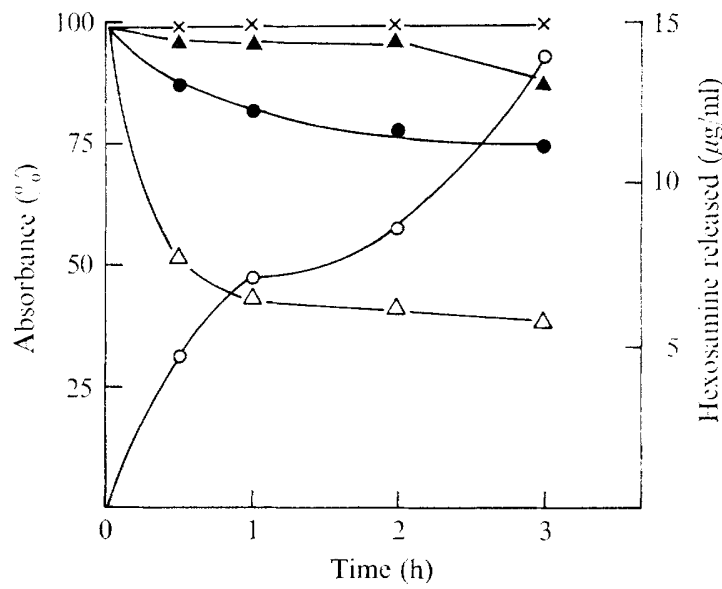

Fig. 7. Hydrolysis of walls from Mucor rouxii, chitin and chitosan by enzyme preparation from Streptomyces sp. Samples $(20 \mathrm{ml})$ of suspensions containing $\mathrm{I} \cdot 0 \mathrm{mg}$ of chitin, chitosan or walls per $\mathrm{ml}$ were incubated at $32^{\circ} \mathrm{C}$ in $7 \mathrm{~mm}$-tris buffer, $\mathrm{pH} 8.0$, with or without enzyme $\left(3^{\circ} \mathrm{O} \mathrm{mg}\right.$ of protein). At intervals, samples were withdrawn and absorbance was measured. After centrifugation the supernatant was analysed for glucosamine released from chitosan and glucosamine and $N$-acetyl glucosamine released from chitin. $\times$, Absorbance of walls, chitin or chitosan suspensions incubated without enzyme; $\boldsymbol{\Delta}$, absorbance of chitin suspension with enzyme; $\boldsymbol{\bullet}$, absorbance of chitosan suspension with enzyme; $\triangle$, absorbance of wall suspensions with enzyme; $\bigcirc$, glucosamine released from chitosan.

\section{Table I. Analyses of solubilized and insoluble material from Mucor rouxii walls incubated with lytic enzyme}

Walls ( $30 \mathrm{mg}$ ) were incubated at $32^{\circ} \mathrm{C}$ for $24 \mathrm{~h}$ with $\mathrm{r} \cdot 8 \mathrm{mg}$ protein of enzyme in a final volume of $15 \mathrm{ml}$ with $50 \mathrm{~mm}$-tris, $\mathrm{pH} 8 \cdot 0$. The material was centrifuged, the residue recovered, washed, freeze-dried and weighed.

\begin{tabular}{lrrrr} 
& \multicolumn{2}{c}{ Supernatant } & \multicolumn{2}{c}{ Residue } \\
Compound & $\overbrace{(\mathrm{mg})}$ & $(\%)$ & $(\mathrm{mg})$ & $(\%)$ \\
Total sugars* & 6.975 & 29.06 & $\mathrm{I} \cdot 230$ & 20.50 \\
Hexosamines* & 10.500 & 43.70 & 2.478 & 41.30 \\
Uronic acids* & 2.164 & 9.01 & 0.762 & $\mathrm{I} 2.70$ \\
Protein & 2.063 & 8.59 & 0.720 & $\mathrm{I} 2.00$ \\
Phosphate $\dagger$ & 2.197 & 9.10 & 0.369 & 6.15 \\
Total & 23.899 & 99.46 & 5.559 & 92.65 \\
& * As the anhydrous form. & \\
& + As phosphorus.
\end{tabular}

incubated with the lytic complex, about 30 to $36 \%$ of total cell $\alpha$-glucosidase was released to the supernatant after $2 \mathrm{I}$ h of incubation. According to data obtained in our laboratory, $\alpha$-glucosidase is a wall-bound enzyme (Flores-Carreón, Reyes \& Ruiz-Herrera, 1970).

Lysis of chitin, chitosan and mucoran (a polymer containing glucuronic acid, mannose, fucose and galactose; Bartnicki-García \& Reyes, 1968) by the enzymatic complex from Streptomyces was tested. Lysis of chitin and chitosan was measured by release of hexosamine or $\mathrm{N}$-acetyl hexosamine respectively and decrease in absorbance. Mucoran lysis was measured by release of reducing material. No activity was observed when mucoran was the substrate. When chitin was used, a slight decrease in absorbance was observed, but no hexosamines or $N$-acetyl hexosamines could be detected in the supernatant. When chitosan 

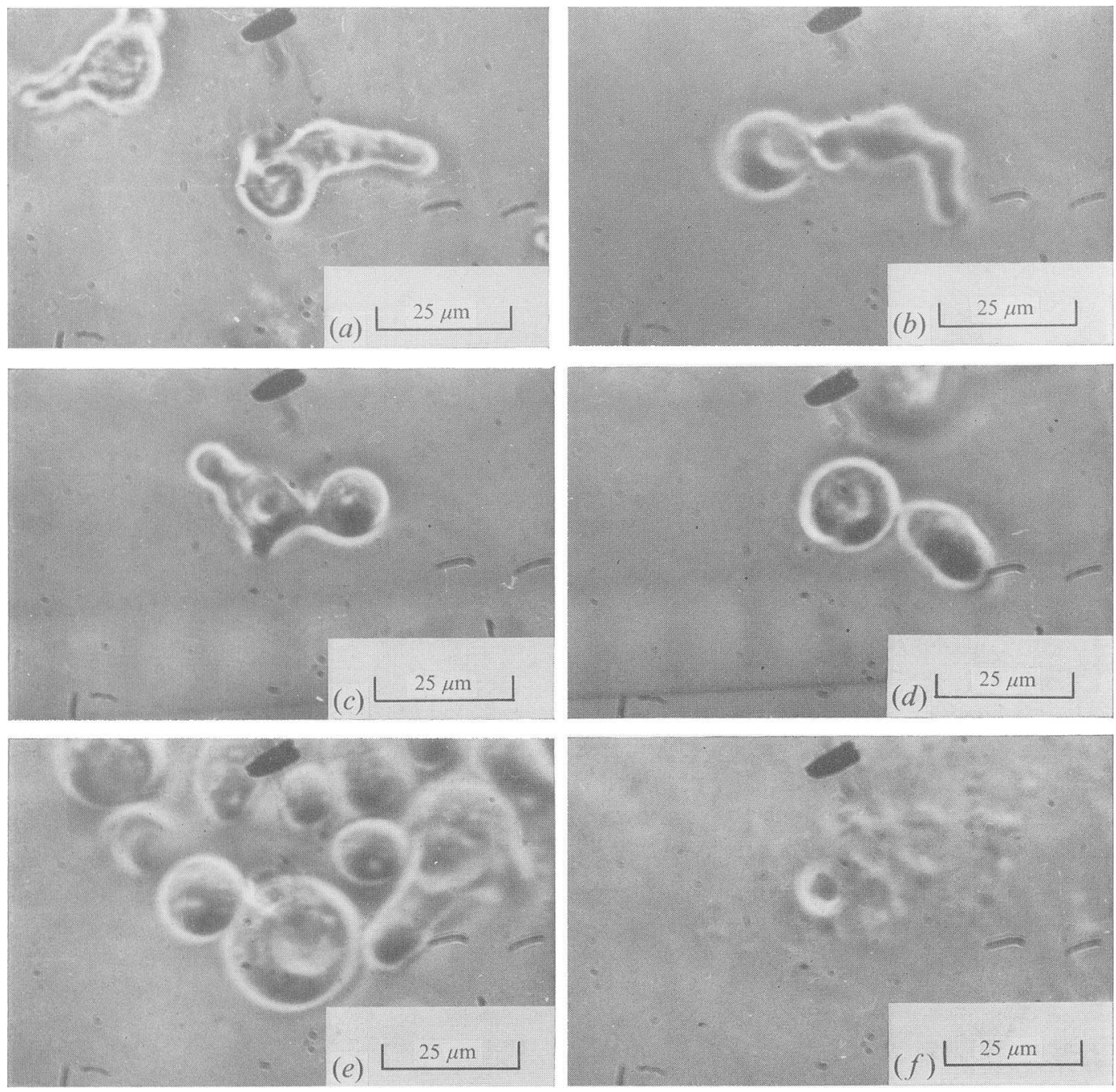

Fig. 8. Morphology of germinated spores and sphaeroplasts from Mucor rouxii. The sphaeroplasts were obtained with Streptomyces enzymatic complex. (a) Germinated spores without enzyme. $(b)$ Initial deformation of hyphae after enzymatic attack. (c) Formation of sphaeroplasts in $25 \%$ sucrose. (d) After dilution of sucrose to $12.5 \%$ germ tubes are pinched off. (e) Enlargement of sphaeroplasts maintained in $8.3 \%$ sucrose. $(f)$ Residue from protoplasts shocked with water.

was used, there was significant decrease in absorbance, and hexosamine was released to the supernatant (Fig. 7).

Formation of sphaeroplasts from Mucor rouxii. Sphaeroplasts were formed when germinated spores of $M$. rouxii were incubated with the enzymatic complex from Streptomyces in the presence of $25 \%$ sucrose. These appeared as spherical bodies. Apparently the wall of the spore was more resistant to enzymatic attack than was the germ tube since the spore's content was emptied into the germ tube which rounded and swelled to become larger than the spore itself. The hyphal apex was the part most susceptible to lysis. When the sucrose medium was diluted, the size of sphaeroplasts increased, and both spore and enlarged germ tube formed a single spherical body, or they separated as two stable spherical bodies. As 


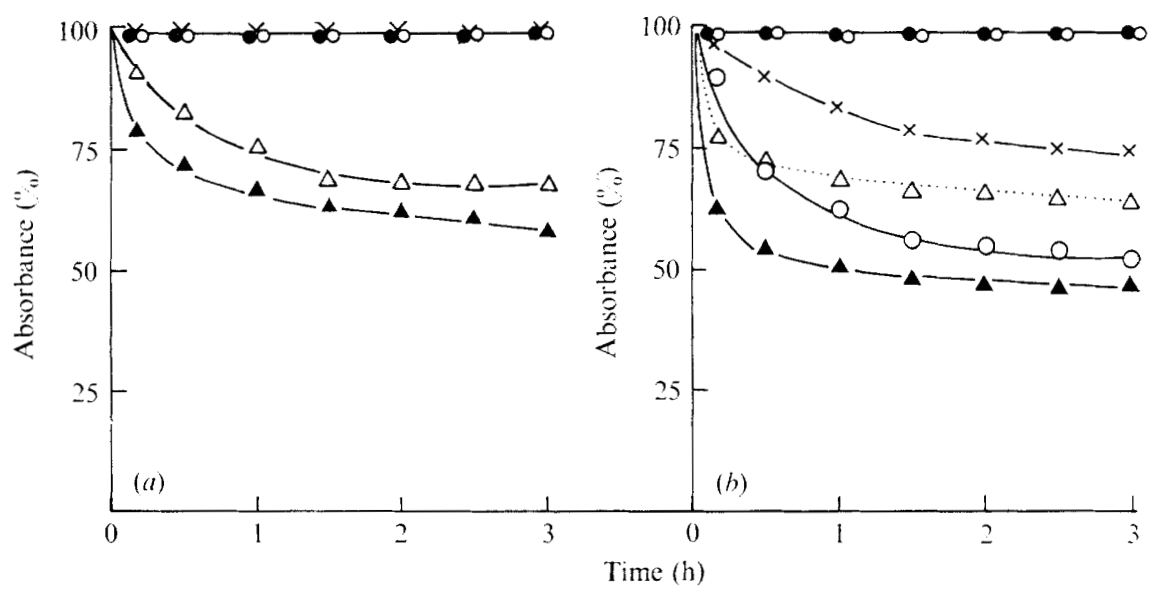

Fig. 9. Degradation of walls from selected species of fungi by Streptomyces enzymatic complex. (a) Suspensions of hyphal walls $(0.3 \mathrm{mg} / \mathrm{ml})$ were incubated in 7 mM-tris buffer, $\mathrm{pH} 8 \cdot 0$, with $0.24 \mathrm{mg}$ protein of crude enzyme. The final volume was $3.0 \mathrm{ml}$ and temperature $32{ }^{\circ} \mathrm{C}$. 9 , Psilocybe caerulescens; 0 , Aspergillus flavus; $\times$, Phytophthora capsici; $\triangle$, Phycomyces blakesleeanus; $\mathbf{\Delta}$, Mucor rouxii. (b) Suspensions of germinated spores $(3 \mathrm{mg} / \mathrm{ml})$ were incubated with lytic enzyme as described above., Aspergillus oryzae; $\bigcirc$, Fusarium solani; $\times$, Cunninghamella echinulata; $\triangle$, Rhizopus nigricans; $\bigcirc$, Rhizopus sp.; $\boldsymbol{\Delta}$, M. rouxii.

the sucrose concentration was lowered to ro to $12 \%$ the sphaeroplasts disintegrated suddenly and left a granular residue. Apparently there were no weaker points in the sphaeroplast envelope which permitted emptying. The appearance of sphaeroplasts maintained in several concentrations of sucrose is shown in Fig. 8.

Hydrolysis of the wall from selected fungi by the enzymatic complex from Streptomyces sp. Activity of the lytic complex was tested on walls isolated from hyphae of Phycomyces blakesleeanus, Psilocybe caerulescens, Aspergillus flavus and Phytophthora capsici, and from germinated spores of Rhizopus sp., Rhizopus nigricans, Cunninghamella echinulata, Aspergillus oryzae, and Fusarium solani. The results appear in Fig. 9, and show that walls from only Mucorales were susceptible to lysis by the enzymatic complex.

\section{DISCUSSION}

Our data suggest that the action of the enzymatic complex obtained from culture filtrates of Streptomyces sp. on the walls of Mucor rouxii was due to the action of one enzyme. Several observations are compatible with the hypothesis. First, it was observed that lytic activity of the filtrate increased with the age of the Streptomyces culture. When culture filtrates obtained after 2 and 8 days of incubation were mixed, no enhancement of wall lysis was observed which suggests that different lytic enzymes were not accumulated. Lysis of walls showed only one optimal $\mathrm{pH}$ in the several buffers tested and only one optimal temperature. When the complex was tested with walls from several fungi, it was observed that only Mucorales were susceptible to lysis. These are the only fungi tested which contain chitosan (Bartnicki-García, I968). Moreover, no reducing material was released from walls obtained from Aspergillus flavus and Psilocybe caerulescens, both of which contain large amounts of glucans (Ruíz-Herrera, I967; F. Esparza, personal communication). Jones et al. (I968) reported that culture filtrates from Streptomyces sp. grown on sporangiospore walls from $M$. ramannianus showed laminarinase activity which was induced by the laminarin- 
type glucan present in such walls. Of the several polymers tested, only chitosan was hydrolysed by the enzymatic complex. Chitin and mucoran were resistant to hydrolysis and no $\mathrm{N}$-acetyl hexosamines were released from isolated wall material. The observations suggest that hydrolysis of the wall is due to the action of an enzyme acting on chitosan but not on chitin. It is known that chitinase hydrolyses chitosan (Jeniaux, I966), but an enzyme specific for chitosan (chitosanase) has not been described, and further experiments to characterize such an enzyme are necessary before reaching a final conclusion. If our hypothesis is correct, lysis of walls from $M$. rouxii would be different from the general pattern observed where more than one enzyme is required for the lysis of fungal and yeast walls (Skujins et al. I965; Tanaka \& Phaff, 1965; Villanueva, I966), and it would be necessary to assume that, like the wall-bound $\alpha$-glucosidase, the other components of the wall from $M$. rouxii are rendered soluble when the anchor material (chitosan), which gives the rigity to the wall, is solubilized. There were only slight chemical differences between the sensitive and resistant fractions of wall material. The simplest explanation is that, as the enzymatic reaction proceeds, the rate of hydrolysis changes because the susceptible substrate becomes less accessible to the enzyme, being protected by some other wall component. According to this hypothesis, given enough time, all the material except that completely inaccessible to the enzyme would be solubilized. Isolated walls were more resistant to the enzyme than the wall formed at spore germination. This suggests that the structures are different and that ageing of walls increases their resistance to enzymatic hydrolysis. We lack an explanation for this phenomenon, but manipulations of the wall, especially freeze-drying, may affect the organization of some resistant material, so making sensitive materials less accessible to the enzyme. The effect of divalent cations, and especially those of heavy metals, suggests that the enzyme contains a sulphydryl group necessary for activity.

Since walls of only Mucorales were lysed with the enzymatic preparation, specific walllysing enzymes may give information on taxonomic and phylogenetic relationships among fungi.

There are numerous reports on the preparation of sphaeroplasts (or protoplasts) from fungi by action of wall-lysing enzymes (Emerson \& Emerson, 1958; Bachmann \& Bonner, 1959; Mitchell \& Alexander, 1963; Rodríguez Aguirre, Garcia Acha \& Villanueva, I964; Villanueva, 1966). Our microscopic observations revealed that the wall of the hyphal tip with the site of wall growth was the most susceptible part. Similar results have been described by Villanueva (1966).

We thank Dr D. Jones from the Macaulay Institute for Soil Research, Aberdeen, Scotland for providing the strain of Streptomyces sp. no. 6. This work was supported by financial help from the C.O.F.A.A. of the Instituto Politécnico Nacional.

\section{REFERENCES}

Ashwell, G. (1957). Colorimetric analysis of sugars. In Methods in Enzymology, vol. III, p. 97. Edited by S. P. Colowick \& N. O. Kaplan. New York: Academic Press.

Bachmann, B. J. \& Bonner, D. M. (1959). Protoplasts from Neurospora crassa. Journal of Bacteriology $7 \mathbf{8}$, $550-556$.

Bartnicki-García, S. (I968). Cell wall chemistry, morphogenesis and taxonomy of fungi. Annual Review of Microbiology 22, 87-108.

BARTNICKI-GARCíA, S. \& Nickerson, W. J. (I962a). Induction of yeast-like development in Mucor rouxii by carbon dioxide. Journal of Bacteriology 84, 829-840.

Bartnicki-García, S. \& Nickerson, W. J. (I962 $b$ ). Isolation, composition, and structure of cell walls of filamentous and yeast-like forms of Mucor rouxii. Biochimica et biophysica acta 58, $102-119$. 
Bartnicki-García, S. \& Reyes, E. (1968). Polyuronides in the cell walls of Mucor rouxii. Biochimica et biophysica acta I70, 54-62.

BitTer, T. \& EwINS, R. (I961). A modified carbazole reaction for uronic acids. Biochemical Journal 8I, 43P.

Dimler, R. J., Schaefer, W. C., Wise, C. S. \& Rist, C. E. (I952). Quantitative paper chromatography of D-glucose and its oligosaccharides. Analytical Chemistry 24, I4I I-I4I4.

EMERson, S. \& EMERSon, M. R. (I958). Production, reproduction and reversion of protoplast-like structures in the osmotic strain of Neurospora crassa. Proceedings of the National Academy of Sciences of the United States of America 44, 668-67I.

Flores-Carrén, A., Reyes, E. \& Ruíz-Herrera, J. (I970). Inducible cell wall-bound $\alpha$-glucosidase in Mucor rouxii. Biochimica et biophysica acta 222, 354-360.

Furuya, A. \& Ikeda, Y. (1960). Studies on the cell wall lytic enzymes produced by Streptomyces species. Journal of General and Applied Microbiology 6, 40-48.

Gascón, S. \& Villanueva, J. R. (1964). Extracellular lytic enzymes of Micromonospora. Canadian Journal of Microbiology 10, $30 \mathrm{I}-303$.

Horikoshi, K. (1959). The effect of lytic enzymes from Bacillus circulans and chitinase from Streptomyces sp. on Aspergillus oryzae. Nature, London $\mathbf{1 8 3}$, I 86-187.

Horikoshi, K. \& IidA, S. (1958). Lysis of fungal mycelia by enzymes. Nature, London 181, 917-918.

Jeniaux, C. (1966). Chitinases. In Methods in Enzymology, vol. viII, p. 644. Edited by E. F. Neufeld \& V. Ginsburg. New York: Academic Press.

Jones, D., BACon, J. S. D., FARMeR, V. C. \& Webley, D. M. (1968). Lysis of cell walls of Mucor ramannianus Möller by a Streptomyces sp. Antonie van Leeuwenhoek 34, I 73-I82.

Lowry, O. H., Rosebrough, N. J., Farr, A. L. \& Randall, R. J. (195I). Protein measurement with Folin phenol reagent. Journal of Biological Chemistry I93, 265-275.

Mitchell, R. \& AleXANder, M. (1961). The mycolytic phenomenon and biological control of Fusarium in soil. Nature, London 190, 109-110.

Mitchell, R. \& AleXander, M. (1963). Lysis of soil fungi by bacteria. Canadian Journal of Microbiology 9 , $169-177$.

Ochoa, A. G., Garcia-Acha, I., Gason, S. \& Villanueva, J. R. (I963). The use of lytic enzymes of Micromonospora spp. to prepare protoplasts of yeasts. Experientia $\mathbf{I 9}, 58 \mathrm{I}-582$.

PARK, J. T. \& Johnson, M. J. (1949). A submicrodetermination of glucose. Journal of Biological Chemistry I8I, I49-I5I.

RAMírez, F., ReYeS, E. \& Ruíz-HERRERA, J. (1970). Spheroplasts from Mucor rouxii. Abstracts XInternational Congress of Microbiology, México, D.F., p. 8.

Reissig, J. L., Strominger, J. L. \& Leloir, L. F. (1955). A modified colorimetric method for the estimation of $N$-acetylamino sugars. Journal of Biological Chemistry 217, 959-966.

Rodriguez Aguirre, M. J., Garcia-Acha, I. \& Villanueva, J. R. (1964). Formation of protoplasts of Fusarium culmorum by strepzyme. Antonie van Leeuwenhoek 3o, 33-44.

Ruíz-Herrera, J. (I967). Chemical components of the cell wall of Aspergillus species. Archives of Biochemistry and Biophysics 122, I 8 - 125.

SALton, M. R. J. (1955). Isolation of Streptomyces spp. capable of decomposing preparations of cell-walls from various micro-organisms, and comparison of their lytic activities with those of certain actinomycetes and myxobacteria. Journal of General Microbiology 12, 25-30.

Skujins, J. J., Potgieter, H. J. \& AleXander, M. (1965). Dissolution of fungal cell walls by Streptomycete chitinase and $\beta$-(I-3)glucanase. Archives of Biochemistry and Biophysics III, 358-364.

TANAKa, H. \& PhafF, H. J. (I965). Enzymatic hydrolysis of yeast cell wall. I. Isolation of wall-decomposing organisms and separation and purification of lytic enzymes. Journal of Bacteriology 89, 1570-1 580 .

TAUSSKY, H. H. \& SHORR, E. (1953). Microcolorimetric method for the determination of inorganic phosphorus. Journal of Biological Chemistry 202, 675-685.

Villanueva, J. R. (I966). Protoplasts of fungi. In The Fungi, vol. II, p. 3. Edited by G. C. Ainsworth \& A. S. Sussman. New York: Academic Press. 